\title{
Compensation in Swedish infrastructure projects and suggestions on policy improvements
}

\author{
Jesper Persson', Anders Larsson', Ana Villarroya² \\ I Swedish University of Agricultural Sciences, Alnarp, Sweden 2 University of Navarra, Pamplona, Spain \\ Corresponding author: Jesper Persson (jesper.persson@slu.se)
}

Academic editor: A. Seiler | Received 19 December 2014 | Accepted 18 June 2015 | Published 28 July 2015

http://zoobank.org/DCC1A510-8DA7-478F-B3CD-9A56F08BF114

Citation: Persson J, Larsson A, Villarroya A (2015) Compensation in Swedish infrastructure projects and suggestions on policy improvements. In: Seiler A, Helldin J-O (Eds) Proceedings of IENE 2014 International Conference on Ecology and Transportation, Malmö, Sweden. Nature Conservation 11: 113-127. doi: 10.3897/natureconservation.11.4367

\begin{abstract}
Environmental compensation includes a range of activities intended to counterbalance such negative impacts of development projects that remain in the environment after all preventive and corrective measures have been fully implemented. Sweden, being a member state of the European Union (EU), must implement environmental compensation under EU directives such as the Habitat Directive. However, like in other countries, implementation is not yet widespread in Sweden, and new practices and guidelines remain to be developed both nationally and at European level. This need is all the more urgent considering that the European Commission estimates that, within the EU, about 100,000 hectares of land is converted from its natural state each year.

The aim of this paper is to describe current environmental-compensation practices in Swedish road and railway projects and to discuss issues of vital importance to the development of compensation policy, such as what to compensate for, how much, and how.

A national inventory was performed, for the first time in Sweden, to identify compensation measures in road and railway projects. Data were collected from a national mailing list including 141 officials at county administrative boards (CABs), internal e-mail correspondence within the Swedish Transport Administration and databases of court decisions. The inventory focused on compensation measures ordered by virtue of the Swedish Environmental Code. In addition, two case studies were carried out to investigate the planning of compensation measures.

The results showed that $\mathrm{CABs}$ and courts rarely order compensation in infrastructure projects, even though this is possible under Swedish law. Between 1999 and 2012, 37 cases (i.e. permits issued) were found for which compensation was ordered. Of these cases, $76 \%$ concerned compensation for encroachments on minor habitats such as small ponds and cairns. No CAB ordered compensation for
\end{abstract}

Copyright Jesper Persson et al. This is an open access article distributed under the terms of the Creative Commons Attribution License (CC BY 4.0), which permits unrestricted use, distribution, and reproduction in any medium, provided the original author and source are credited. 
non-protected areas. Compensation ratios were never explicitly mentioned in permits, but in practice a ratio of 1:1 (often measured as area or length) was usually applied. The compensation measures typically consisted in recreating the same kind of natural asset that was affected, in a location close to the damaged area. In the two cases specially studied, the road and railway planning processes were not properly adjusted to integrate compensation issues, resulting in unnecessary bureaucracy and insufficient co-ordination between different projects, such as between the environmental-impact assessment process and the compensation process or between closely related sub-projects in the same region.

To meet the EU's goal of no net loss of biodiversity, we suggest that policy requirements should be made stricter and that incentives for voluntary compensation should be created. In line with the goals of Swedish national transport policy and the European Landscape Convention, account should be taken of social and cultural aspects, and there should be a shift from a narrow focus on individual projects to a broader planning approach, since this would allow compensation measures to be taken where they can deliver the greatest environmental benefits.

\section{Keywords}

Planning, Environmental compensation, Inventory, Infrastructure, Policy

\section{Introduction}

The idea of environmental compensation is far from new. This may not be so surprising, given that it is essentially based on the polluter-pays principle and the idea that people should make amends for their actions (Persson 2013). It may be defined as the provision of positive environmental measures to correct, balance or otherwise atone for the loss of environmental resources (Cowell 2000). Today, environmental compensation is established across the world both in legislation and in voluntary commitments by companies and local authorities (Rainey et al. 2014). However, environmental compensation is not just about making sure that developers and others abide by the polluter-pays principle. The world's access to sustainable environment is coming under ever-greater pressure and the need to take care not only of protected natural areas but also of the 'everyday landscape' is increasing both in Sweden and globally. The European Commission estimates that, within the European Union (EU), about 100,000 hectares of land is converted from its natural state each year as a result of industrial and urban development and infrastructure projects. In the Commission's opinion, somewhere between half and all of this loss should be compensated for each year (ICF GHK 2013). In Sweden, like in many other EU and other European countries such as Norway, environmental compensation has not fully come into use yet and few guidelines have been developed (Samferdseldepartementet 2013, Villarroya et al. 2014). Moreover, there is no information about how widespread the use of environmental compensation is.

Environmental compensation has been in use for longer in some countries, such as the United States and Germany, as described by McKenney (2005), Darbi et al. (2009) and Tucker et al. (2013). However, their experiences may not be fully transferable to other countries, meaning that each country and organisation must also consider 
its own particular context when developing guidelines and policies. In addition, there are controversial and difficult questions to be tackled, such as what environmental aspects to compensate for, what techniques to use (the available ones include e.g. re-establishment, creation and enhancement), whether to carry out compensation measures close to the damaged nature or not (on-site vs. off-site), and whether the type of compensation should reflect the damage or not (in-kind vs. out-of-kind) (Persson 2013). Another crucial issue is the problem of finding land suitable for mitigation measures (Wende et al. 2005; Rundcrantz 2007). To this should be added that infrastructureplanning and environmental-compensation processes are complex and difficult to deal with on the basis of individual perspectives from planning theory, given that they include not only strategic/rational but also incremental/pragmatic and communicative aspects (e.g. Sager 2001, Wolf and Floyd 2013, Allmendinger 2002). For this reason, the starting point of our discussion will instead be ethical principles, the European Landscape Convention and scientific research.

The aim of this paper is to describe the current state of environmental-compensation practice in Swedish road and railway projects and to discuss issues of vital importance to the development of compensation policy, such as what to compensate for, to what extent (i.e. compensation ratios), and how.

\section{Method - inventory and case studies}

No previous nationwide inventory had been performed in Sweden of the extent to which environmental compensation is used, either in general or in conjunction with road and railway projects. To form an idea of the number of compensation measures carried out for projects involving an investment by the Swedish Transport Administration since 1999, when the possibility and/or requirement to order such measures was introduced in the Swedish Environmental Code, the approach chosen involved identifying projects that had been examined on the basis of the Environmental Code and where an order to carry out compensation measures had been issued, as well as studying the conditions for compensation laid down by the authorities issuing such orders. Under the Swedish Environmental Code, the authority examining a project must order environmental compensation if Natura 2000 areas or nature reserves are affected, and it may also choose to order compensation by virtue of provisions relating to protected biotopes, the protection of species and effects on aquatic environments.

To begin with, all instances of examination by public authorities were included, i.e. those carried out by municipalities (local authorities) and county administrative boards (CABs) as well as those carried out by courts of law. A first search of legal databases (www.zeteo.se, www.karnov.se, www.lagrummet.se and www.infotorgjuridik.se) returned no court decisions; however, at a later stage of the project, two infrastructure projects were found that involved cases where courts had ordered compensation. One of the two projects involved ten cases relating to water rights, all pronounced by the Land and Environment Court of Vänersborg. The other project involved numerous 
decisions and appeals; it turned out to be too complex to be fully included in the inventory. The results reported below are therefore limited to decisions made by CABs and municipalities.

The inventory was carried out by means of two questionnaire surveys. One was sent out on 16 November 2012 as an internal mailing within the Swedish Transport Administration. The other was sent on 19 November 2012 to all CABs through a mailing list for officials handling nature-conservation cases; it included 141 addresses. Telephone calls were made in January and February 2013 to those CABs that had not yet responded. Here it should be noted that this approach did not necessarily capture all cases of environmental compensation, since compensation measures do not have to follow from formal examination under the Environmental Code but may also be undertaken on a voluntary basis. However, voluntary compensation is probably not that usual; only six such cases were identified through interviews and other methods.

Two cases, one from Järfälla near Stockholm and one from Umeå, were studied more closely. In both of these cases, concrete work on the environmental impact assessment (EIA), environmental compensation, etc., started around 2010, but this was of course preceded by a lengthy preparatory phase. The criteria used to select cases were that they should represent both municipal and CAB decisions and both road and railway projects, and that they should be relatively complex and involve several different aspects of compensation. Preferably, some time should also have passed so that it would be possible to study the entire planning and implementation process. The two cases selected were the only ones that fully met the criteria. We could also have chosen several smaller, more specific cases in specific counties, using a 'county' criterion as the basis for selection, but we decided to restrict our study to the two above-mentioned cases because they complement each other very well. All documents relating to the compensation issues in these two cases that we were able to find were studied closely. The remaining documentation (such as the EIA and the work schedule) was studied in a more cursory manner. Project leaders were interviewed over the telephone and given complete freedom to describe their version of the course of events. Supplementary and follow-up questions where we had identified points of unclarity were asked both over the telephone and by e-mail, and we also contacted other involved parties in individual cases (by telephone or e-mail).

\section{Environmental compensation in Swedish infrastructure projects}

\section{Decisions taken by municipalities and CABs}

The most remarkable finding is that the inventory yielded relatively few cases: only 37 decisions. It is difficult to quantify the total number of road and railway projects planned or implemented since 1999; however, it can be noted that the Administration allocates more than 4 billion euros each year to the building, operation and maintenance of infrastructure. The earliest case found was from 2004; since 2008, the average 
number of cases per year has been slightly below seven. Of all 37 cases identified, 12 related to railways, 22 to roads and 3 to both. Further, CABs accounted for 36 of the 37 decisions found while only a single one was made by a municipality.

By way of comparison, it can be noted that compensation requirements seem to be more common in Spain. Of all road and railway projects approved by Spanish national and regional authorities in 2006 and 2007, 40\% (85 out of 214) included provisions regarding compensatory measures (Villarroya and Puig 2010). This percentage dropped to 22\% (16 out of 72) for infrastructure projects approved between 2009 and 2011 (Villarroya 2012).

Table 1 shows the Swedish public authorities having made the decisions identified as well as the provisions of the Environmental Code referred to by them. Note that a decision (right-hand column) may refer to several provisions (the central, lighter columns). For some projects, a first decision was followed by a second, more specific one. In such cases, the second decision overrules the first one (meaning that this does not count as two decisions). By contrast, where a stretch of road was divided into several parts for which separate applications were submitted, this has been counted as one decision per application. The vast majority of decisions were associated with habitat protection (i.e. protection of small ponds and cairns), which the decision-making authority referred to in 28 out of 37 cases (76\%), and with encroachment on nature

Table I. Decisions taken by Swedish county administrative boards (CABs) and municipalities in 19992012 involving an order for environmental compensation. Note that a decision may refer to more than one legal provision; the right-hand column indicates the actual number of decisions.

\begin{tabular}{|c|c|c|c|c|}
\hline & \multicolumn{3}{|c|}{ Legal provision relating to } & \multirow{2}{*}{ Number of decisions } \\
\hline & protected areas ${ }^{1)}$ & protection of species ${ }^{2)}$ & water use ${ }^{3)}$ & \\
\hline \multicolumn{5}{|c|}{ Swedish county administrative boards (total number: 21 ) } \\
\hline Blekinge & 1 & & & 1 \\
\hline Gävleborg & & & 1 & 1 \\
\hline Stockholm & 1 & & & 1 \\
\hline Värmland & 1 & 1 & & 1 \\
\hline Västerbotten & 1 & & & 1 \\
\hline Västernorrland & 1 & & & 1 \\
\hline Västra Götaland & 23 & 1 & 1 & 24 \\
\hline Östergötland & 5 & 1 & & 6 \\
\hline \multicolumn{5}{|c|}{ Municipality (total number: 290) } \\
\hline Järfälla & 1 & & & 1 \\
\hline Total & $34^{4)}$ & 3 & 2 & 37 \\
\hline
\end{tabular}

1) Chapter 7 of the Environmental Code (SFS 1998:808), which concerns, inter alia, habitat protection, Natura 2000 areas, nature reserves and the protection of shorelines.

2) Species Protection Ordinance (SFS 2007:845). Ordinances are regulations issued by the Government. This and the next ordinance were issued in implementation of provisions of the Environmental Code proper.

3) Water Use Ordinance (SFS 1998:1388).

4) Where 28 concerned habitat protection (i.e. protection of small ponds and cairns). 
reserves and Natura 2000 areas. Of all 37 decisions, 34 (92\%) involved one or both of these categories. No decision related to compensation for damage to the everyday landscape (i.e. non-protected nature). It also turned out that most CABs had not taken a single decision ordering compensation measures. Of the $21 \mathrm{CABs}, 13$ had never ordered compensation and 6 had done so in a single case only, meaning that $90 \%$ of the $\mathrm{CABs}$ had adopted either no such decision or only one. The CAB of Västra Götaland accounted for 24 of the 37 decisions (65\%) on its own.

\section{Design of requirements}

Of the 37 decisions, 32 lay down specific requirements to be met by the compensation measures while 2 of them state that the measures are to be designed later and 3 of them provide for compensation in the form of an amount of money being allocated to a fund. Further, the inventory showed that the compensation measures tended to resemble the damage done and that the prevailing view is that the measures should be on a par with the intervention, i.e. that the compensation ratio should be 1:1. A typical example is a habitat-protection case in eastern Sweden (Lilla Edet on route E45) where an encroachment entailing the loss of $152 \mathrm{~m}$ of stone walls and $176 \mathrm{~m}$ of open ditches was compensated for through the addition of $150 \mathrm{~m}$ of new stone walls and $150 \mathrm{~m}^{2}$ of new wetland (Länsstyrelsen Västra Götalands län 2011).

\section{Planning perspectives}

\section{Two cases}

Two cases were studied in greater detail: (1) Röbäck/Röbäcksdalen, a project to build a new bypass on route E12 west of Umeå in relation to which the CAB ordered compensation measures; and (2) Järfälla, a project involving the expansion from two to four tracks of the railway stretch between Barkarby and Kallhäll in conjunction with the Mälarbanan line between Stockholm and Örebro, where the compensation order was issued by the municipality. The purpose of these two case studies was not only to illustrate the practicalities of environmental-compensation cases, but also to highlight a few concrete examples of implementation problems and opportunities for improvement from a planning perspective.

The Röbäck case is a rather traditional habitat-protection case, but a large and complex one. Its outcome was that an encroachment on a Natura 2000 area was compensated for through the establishment of a new nature area elsewhere. It was not possible to do this within the actual Natura 2000 area because of difficulties relating to land ownership, as revealed by the interviews - a large number of private land owners would have been involved, the situation regarding financial compensation and management issues was unclear, and the Swedish Transport Administration lacks the 
power to expropriate land for compensation measures. Therefore it was decided to use land owned by the municipality instead. The Järfälla case, by contrast, represents a broader problem complex because the expansion of the railway will entail both an encroachment on a nature reserve and impacts on the natural and cultural environment as well as on opportunities for outdoor and recreational activities. The Swedish Transport Administration was therefore ordered to compensate for the encroachment and impacts involved, for example by moving cultural remains and by building new bridges for better access to the recreation area by foot or bicycle as well as eco-passages. The compensation process in the Järfälla case has proceeded smoothly and the various interested parties have co-operated well. Measures have begun to be planned and implemented, and issues of maintenance are being discussed.

\section{General problems: transparency and co-ordination}

One general conclusion drawn from the case studies was that both projects were highly dependent on the skill of the parties involved and on their will to carry through the compensation measures in the best possible way. Rundcrantz (2007) draws similar conclusions from her case studies. However, an environmental expert from the Transport Administration noted that it was difficult even for those involved to grasp the whole process, and that the actual outcome was finally determined by a 'tug-of-war' between different actors as well as by legal and practical issues (Persson et al. 2014). Both projects seem likely to attain good final results, but it is very difficult for external reviewers to form a clear picture of the entire planning process based on the official documents.

A further conclusion specific to the Röbäck case concerns the fact that, in recent years, the region around Umeå - especially the many bird-protection areas to be found there - has seen the implementation of a large number of major road and railway projects giving rise to orders for environmental compensation. However, in the Röbäck case it was difficult to gain access to the various formal documents that circulated in relation to each individual part of the road project, not to mention experiences made by the various involved parties that had not actually been written down anywhere. One might think that by now some form of regional co-ordination of the environmental issues concerned would have evolved. This should have been able to bring about not only a more coherent approach both to the assessments and to the interaction between them, but also a package of environmental measures yielding maximum nature-protection benefit. That would have greatly enhanced both efficiency and transparency.

As regards the Järfälla case, it turned out that sub-projects that should in theory be capable of co-ordination, such as the EIA for the work schedule and the compensation case, were in fact carried out separately and in parallel, with no systematic cross-referencing. Indeed, sometimes the same individuals were involved in preparing parallel information for different documents. As a result, those documents may be very 
similar in part while there are also clear differences between them; in the absence of an explanation, this may be confusing to external reviewers (indeed, it was not clear to us until we had the opportunity to ask some follow-up questions in a second interview). In all likelihood, each individual sub-project has its own planning, budget, staff, etc., meaning that the work is governed by a project-based logic rather than being part of a coherent process where the site and the problems are in focus. From the perspectives of transparency and efficiency, it should be possible to achieve improvements through a clearer formal description of how compensation cases are to be incorporated in the overall road- or railway-planning process, as previously discussed by e.g., Rundcrantz (2007). It might also be a good investment to ensure that there is a regional project co-ordinator who knows the region well and is aware of all ongoing road and railway projects, in order to avoid duplication of work, further enhance transparency and increase efficiency.

\section{Discussion - policy implications}

\section{Why compensate?}

Before discussing the policy implications of environmental compensation, it might be a good idea first to ask why anyone should undertake compensatory efforts in the first place. A list of arguments for and against compensation can be found in Persson (2011). These arguments are important to keep in mind when advocating the use of voluntary compensation. The principal arguments in favour are the following:

- There is an ethical responsibility to preserve common (i.e. public, in the sense that they are enjoyed by many people) goods such as nature. This is in line with the idea of ecosystem services: nature provides humans with benefits, and destroying the capacity of nature to do so will decrease the quality of life of humans (Cuperus et al. 2001, BBOP 2009).

- People should make amends for their actions. This argument rests on the polluterpays principle (European Commission 2001, Beder 2006).

- The overall stock of environmental assets should not be reduced. This is also the rationale behind the principle of the mitigation hierarchy. This hierarchy consists of four (sometimes counted as three) consecutive steps: first, avoid causing impacts; second, minimise any impacts that cannot be avoided; third, restore any impacts that cannot be minimised; and fourth, compensate for or offset any remaining damage that could not be avoided, minimised or restored (see, e.g., BBOP 2009). Skipping any one of these steps may undermine environmental sustainability.

To this should be added that there is reason to believe that a smart use of environmental compensation will shorten planning processes and reduce conflicts (Pers- 
son 2006, Samferdseldepartementet 2013). Not unexpectedly, surveys on attitudes have shown there to be strong support for environmental compensation, even though they also identified some concern that the system may be abused by authorities and developers (Rundcrantz 2005, Persson 2013). In other words, there are both factual arguments and popular support in favour of the claim that the Swedish Transport Administration and corresponding authorities in other countries should pursue the issue of environmental compensation.

One way of increasing the use of environmental compensation is to improve the relevant legislation. However, considering the arguments above, it may well be that an even more important action to take in order to increase its use is to draw attention to all of its advantages so as to promote voluntary compensation.

\section{What to compensate for?}

The inventory showed that compensation had mainly been undertaken by reference to habitat and species protection, and also that no compensation order had been issued in relation to encroachment on the everyday landscape, i.e. unprotected areas, whose importance has been increasingly stressed by numerous authors (e.g., Rundcrantz 2007, ICF GHK 2013). This focus on biodiversity and on specific objects (such as wetlands and cairns) is a result of the approach presently taken in the Swedish Environmental Code, which focuses, as mentioned above, on habitat and species protection but ignores social, health and cultural aspects. This means that a number of environmental assets and ecosystem services are not taken into account. Examples of neglected issues include:

- the impact on cultural environments or characteristic features of the landscape;

- the risk of ill-health (caused, for example, by noise and air pollution);

- opportunities for recreation;

- encroachments that affect farming, forestry, fisheries or other land-dependent economic activities, such as by reducing the amount of arable land.

The legislators adding provisions on environmental compensation to the Environmental Code may not have included these issues, but they still underpin not only the concept of sustainable development but also initiatives such as the European Landscape Convention. It should also be noted that an emphasis on habitat and species protection similar to the one in Swedish legislation exists in countries such as Norway and Germany, whereas aesthetical values are given more weight in the corresponding British legislation (Thompson et al. 1997, Samferdseldepartementet 2013). Hence, even though there is a general focus on biodiversity, it is up to each country to decide what will be compensated for. When it comes to voluntary compensation, obviously, there is even greater freedom of choice. 


\section{How extensive should compensation measures be?}

The inventory showed that the level of compensation ordered was on a par with the extent of the intervention - in practice, the compensation ratio was thus 1:1. There is a Swedish legal precedent in the form of a decision by the Land and Environment Court of Appeal (Miljööverdomstolen 2002) from which it follows that authorities granting permits may not demand too much: the amount of compensation must be reasonable for both sides, i.e. both for the developer and for the public interest. What, then, is 'reasonable' in this context? Below is a list of good reasons for compensating by more than $1: 1$.

- Time. The economic way of looking at the allocation of benefits and costs is based to a large extent on discounting. This means that a compensation measure is worth more today than in ten or twenty years - not because, say, an actual wetland today could not have the same functions as an identical future wetland, but because the services provided by the wetland can be used immediately (Cole 2010).

- Uncertainty. Whenever a compensation measure is taken, there is some uncertainty as regards how the relevant functions will develop and work in the future (Maron et al. 2012). Even if the best available knowledge is used, there are many potential problems, ranging from the specification, implementation and maintenance of the work to the possible failure of nature to abide by the scientific models believed to be valid. Such shortcomings in models may relate, for example, to how a certain species goes about establishing itself or to how a water system reduces the amount of nutrients.

- Quality. Many US states have guidelines for how to weight different technical solutions when comparing them. For example, restoration is seen as more valuable than the creation of new environments, and the creation of new environments is seen as more valuable than the granting of protection for an area (National Research Council 2001).

- Actors involved. When the reasonableness of measures is discussed from the perspective of the different actors involved, issues specially focused on are whether the assessment of reasonableness differs between actors, how they perceive situations differently and how specific mitigation measures would work in each of their contexts (e.g. in out-of-kind and off-site compensation). This is especially important when it comes to compensating for social aspects (Persson 2006).

When ecological criteria are applied, high compensation ratios may be needed to guarantee a fair exchange (Maron et al. 2012). It should be noted that such ratios may be perceived as 'over-compensation' by certain actors, since other criteria (such as hydrological models) will typically yield lower ratios. Also, high compensation ratios may be needed to compensate for damage to recreational and other social areas. Further, it should be kept in mind that environmental disputes typically involve several 
perspectives and interests besides the matter of the correctness of scientific models (Söderbaum 2000, Persson 2006). Ideally, a ratio that is high enough to satisfy all environmental aspects that need to be compensated for should be chosen.

\section{How and where to compensate?}

It is clear from the inventory that Swedish decision-making authorities have consistently proposed compensation measures of the same type as the intervention and usually also located close to the intervention (i.e. 'in-kind' and 'on-site' compensation). This was also the case in Järfälla (however, an exception could be seen in the Röbäck case, where the mitigation measures were out-of-kind and located off-site). This is in line with a principle which is advocated in the guidelines of the Business and Biodiversity Offset Programme (BBOP 2009) and which has been very influential not only within the EU (Tucker et al. 2013) but also in non-EU countries such as Norway (Samferdseldepartementet 2013). By contrast, others have argued that it is important to take a flexible view and adjust the compensation measures to suit each case, because each case is unique - or, as Cuperus et al. (1999:46) put it, '[g]eneral standards and guidelines for choosing between "on-site/ off-site" and "in-kind/out-of-kind" compensation cannot be given, as these depend on the availability of suitable compensation sites and must therefore be determined on a case-by-case basis'. Paradoxically, alongside the BBOP's focus on on-site compensation there is a worldwide trend for compensation to be provided off-site because of problems finding places for the environmental measures. This trend is likely to continue in Europe and elsewhere, given that mechanisms such as 'habitat banking' are also promoted by the European Commission (Conway et al. 2013) and national governments such as the ones in Germany (Wende et al. 2005) and the United States (Race and Fonseca 1996, Federal Register 2000, Stein et al. 2000, U.S. Army Corps of Engineers 2010).

The core of this issue can be summed up as follows: on-site and in-kind compensation is a way to make a contribution close to the site of the damage in order to safeguard local assets (such as ecosystem services), while off-site and out-of-kind compensation may be a necessary option for the promotion of assets of a more general type deemed to be more important or in cases where it is not possible to find an on-site and in-kind option, i.e. in the context of a strategy governed by objectives (Villarroya et al. 2014). The use of the kind of overall landscape perspective characteristic of the latter approach leads to greater flexibility and makes it easier to find locations for compensation measures. In addition, landscape-scale planning allows a more effective implementation of the mitigation hierarchy and prevents overlooking cumulative impacts (Kiesecker et al. 2010). It is true that objections have been made to off-site and out-of-kind compensation based on the hypothesis that it may be easier to gain the acceptance of the general public for onsite and in-kind compensation (ten Kate et al. 2004). However, no studies confirming this have been found and a study of preferences as regards environmental compensation actually showed the opposite hypothesis to be closer to the truth (Persson 2013). 


\section{Conclusions}

A national inventory was performed, for the first time in Sweden, to identify compensation measures in road and railway projects. The results showed that CABs rarely order compensation in infrastructure projects, even though this has been possible under Swedish law since 1999. When compensation measures are ordered, they are typically intended to compensate for encroachments on minor habitats such as small ponds and cairns $(76 \%)$ or for damage to nature reserves or Natura 2000 areas. This is because these aspects are the ones addressed in the Swedish Environmental Code, and so it is in relation to them that developers need to obtain permits from county administrative boards. Hence legislation plays a crucial role in determining what is compensated for. No cases were found where compensation was ordered for non-protected areas. The actual measures mainly amount to the recreation of the same kind of natural asset that was affected, with a compensation ratio of 1:1. In the two cases specially studied, the road- and railway-planning processes were not properly adjusted to integrate compensatory issues, resulting in unnecessary bureaucracy and insufficient co-ordination between different projects, such as between the EIA process and the compensation process or between closely related sub-projects in the same region.

The study shows that the use of environmental compensation is neither well developed nor widespread. To increase the use of compensation, there is a need for further policy development - but it may actually be even more important to draw attention to all of the advantages of environmental compensation in order to promote voluntary compensation and compensation directed towards non-protected areas, i.e. people's 'everyday landscape'. It may be useful to consider the following aspects in the development of new practices, both in Sweden and elsewhere:

- 'Nature' or 'the environment' should be understood broadly to encompass all relevant dimensions, including recreational opportunities, farmland, noise, climate, culture, etc.

- Compensation ratios higher than 1:1 should be used in order to take account of the perspectives of different actors and the issues of time, uncertainty and quality.

- To prevent inconsistencies when several projects are being planned in parallel, an overall landscape perspective yielding increased flexibility should be used, so that cumulative impacts can be taken into account and so that the effectiveness of mitigation and compensation measures can be enhanced. When used within the context of the mitigation hierarchy, tools such as habitat banking may assist the implementation of compensation in certain cases.

- The planning process should be transparent and well co-ordinated with other regional activities. 


\section{References}

Allmendinger P (2002) Towards o Post-Positivist Typology of Planning Theory. Planning Theory 1: 77, 77-99. doi: 10.1177/147309520200100105

BBOP (2009) Biodiversity Offset Design Handbook. Buisiness and Biodiversity Offset programme (BBOP). Washington.

Beder S (2006) Environmental principles and policies: an interdisciplinary introduction. Earthscan, Sterling, Va.

Cole S (2010) Environmental compensation using Resource Equivalency Analysis (REA) and Habitat Equivalency Analysis (HEA): is it just for the birds? PhD thesis. Dept. of Forest Economics, Swedish University of Agricultural Sciences, Umeå.

Conway M, Rayment M et al. (2013) Exploring potential demand for and supply of habitat banking in the EU and appropriate design elements for a habitat banking scheme: Final Report submitted to DG Environment, GHK Consulting Ltd., London.

Cowell R (2000) Environmental Compensation and the Mediation of Environmental Change: Making Capital out of Cardiff Bay. Journal of Environmental Planning and Management 43: 689-710. doi:10.1080/713676580

Cuperus R, Canters KJ, Canters KJ, Udo De Haes HA, Friedman DS (1999) Guidelines for ecological compensation associated with highways. Biological Conservation 90(1): 41-51. doi: 10.1016/S0006-3207(99)00007-5

Cuperus R, Bakermans MMGJ, Udo De Haes HA, Canters KJ (2001) Ecological compensation in Dutch highway planning. Environmental Management 27: 75-89. doi: 10.1007/ s002670010135

Darbi M, Ohlenburg H, Ohlenburg H, Herberg A, Skambracks D, Herbert M (2009) International approaches to Compensation for Impacts on Biodiversity: Final Report. Leibniz Institute, Berlin University of Technology, Dresden, Berlin.

European Commission (2001) Environment 2010: 2001-2010 6th EU Environment Action Programme Our Future, Our Choice. Office for Official Publications of the European Communities.

Federal Register (2000) Federal Guidance on the Use of In-Lieu-Fee Arrangements for Compensatory Mitigation Under Section 404 of the Clean Water Act and Section 10 of the Rivers and Harbors Act; Notice. Department of the Army Corps of Engineers. Vol. 65, No. 216: 66914-66917.

ICF GHK (2013) Exploring potential demand for and supply of habitat banking in the EU and appropriate design elements for a habitat banking scheme: Final Report submitted to DG Environment, London.

Kiesecker JM, Copeland H, Pocewicz A, McKenney B (2010) Development by design: blending landscape-level planning with the mitigation hierarchy. Front Ecol Environ 8: 261-266. doi: 10.1890/090005

Länsstyrelsen Västra Götalands län (2011) Biotopskyddsdispens för utbyggnaden av väg E45 I Lilla Edets kommun. Naturvårdsenheten, Beslut 2011-09-21, Diarienummer: 521-641-2011. 
Maron M, Hobbs RJ, Moilanen A, Matthews JW, Christie K, Hobbs RJ, Moilanen A, Matthews JW, Christie K, Gardner TA, Keith DA, Lindenmayer DB, McAlpine CA (2012) Faustian bargains? Restoration realities in the context of biodiversity offset policies. Biol Conserv 155: 141-148. doi: 10.1016/j.biocon.2012.06.003

McKenney B (2005) Environmental Offset Policies, principles, and Methods: A Review of Selected Legislative Frameworks. biodiversityneutralinitiative.

Miljööverdomstolen (2002) Tillstånd till anläggning för avloppsrening. 2002-11-25, 2002: 80.

National Research Council (2001) Compensating for wetland losses under the Clean Water Act. National Academy Press, Washington, DC.

Persson J (2006) Theoretical reflections on the connection between environmental assessment methods and conflict. Environmental Impact Assessment Review 26(7): 605-613. doi: 10.1016/j.eiar.2006.04.005

Persson J (2011) Att förstå miljökompensation. Melica Media, Göteborg.

Persson J (2013) Perceptions of environmental compensation in different scientific fields. International Journal of Environmental Studies 70(4): 611-628. doi: $10.1080 / 00207233.2013 .835526$

Persson J (Ed.) (2014) Miljökompensation vid väg- och järnvägsprojekt: identifiering av status, problem och möjligheter. Rapport 2014: 24. Fakulteten för Landskapsplanering, trädgårds- och jordbruksvetenskap, Sveriges Lantbruksuniversitet, Alnarp.

Race M, Fonseca S (1996) Fixing compensatory mitigation: What will it take? Ecological Applications 6(1): 94-101. doi: 10.2307/2269556

Rainey HJ, Pollard EHB et al. (2014) A review of corporate goals of No Net Loss and Net Positive Impact on biodiversity. Oryx, 1-7.

Rundcrantz K (2005) Enkät om miljömässig kompensation I samband med byggen av statliga vägar. Vägverket Skåne, Kristianstad.

Rundcrantz K (2007) Environmental compensation for disrupted ecological functions in Swedish road planning and design. PhD thesis. Dept. of Landscape Architecture, Swedish University of Agricultural Sciences, Alnarp.

Sager T (2001) A planning theory perspective on the EIA. In: Hilding-Rydevik T (Ed.) EIA, large development projects and decision-making in the Nordic countries. Nordregio Report 2001: 6, 197-222.

Samferdseldepartementet (2013) Fysisk kompensasjon for jordbruks- og naturområder ved samferdselsutbygging. Oslo, Norge.

Stein ED, Tabatabai F et al. (2000) Wetland Mitigation Banking: A Framework for Crediting and Debiting. Environmental Management 26(3): 233-250. doi: 10.1007/s002670010084

Söderbaum P (2000) Chapter 6: Environmental Management and Decision-making: A political economics approach. In: Ecological economics: A political economics approach to environment and development. Earthscan, London.

ten Kate K, Bishop J et al. (2004) Biodiversity offsets: Views, experience, and the business case. Cambridge, UK.

Thompson S, Treweek J, Thurling D (1997) The ecological component of environmental impact assessment: a critical review of British environmental statements. Journal of Environmental Planning and Management 40: 157-171. doi: 10.1080/09640569712164 
Tucker G, Allen B et al. (2013) Policy Options for an EU No Net Loss Initiative, Report to the European Commission. Institute for European Environmental Policy, London.

U.S. Army Corps of Engineers (2010) Compensatory Mitigation Rule: Improving, Restoring, and Protecting the Nation's Wetlands and Streams. http:/www.epa.gov/owow/wetlands/ pdf/Mit_rule_QA.pdf [Retrieved 7 May, 2010]

Wende W, Herberg A, Herzberg A (2005) Mitigation banking and compensation pools: improving the effectiveness of impact mitigation regulation in project planning procedures. Impact Assessment and Project Appraisal 23: 101-111. doi: 10.3152/147154605781765652

Villarroya A (2012) Ecological compensation and Environmental Impact Assessment in Spain: current practice and recommendations for improvement. $\mathrm{PhD}$ thesis. Department of Zoology and Ecology, University of Navarra, Pamplona, Spain. http://bit.ly/N4ftVR

Villarroya A, Persson J et al. (2014) Ecological compensation: From general guidance and expertise to specific proposals for road developments. Environmental Impact Assessment Review 45(0): 54-62. doi: 10.1016/j.eiar.2013.12.003

Villarroya A, Puig J (2010) Ecological compensation and Environmental Impact Assessment in Spain. Environmental Impact Assessment Review 30(6): 357-362. doi: 10.1016/j. eiar.2009.11.001

Wolf C, Floyd SW (2013) Strategic Planning Research: Toward a Theory-Driven Agenda. Journal of Management, 1-35. doi: 10.1177/0149206313478185 